\title{
The Effect of Giving Date Palm Juice on the Duration of the First Stage of Labor in Sele Be Solu Hospital, Sorong City
}

\author{
Ariani Pongoh ${ }^{1}$, Niken Kumala Budi ${ }^{1}$, Sri Ayu Dawam ${ }^{1}$ \\ ${ }^{1}$ Lecturers of Midwifery Department of Poltekkes Kemenkes Sorong, West Papua
}

\begin{abstract}
The maternal mortality rate (MMR) in the world in 2017 is 216 per 100.00 live births and $99 \%$ of them are due to childbirth problems in Indonesia. One of the causes of maternal mortality in Indonesia is prolonged labor. The labor process requires optimal energy and stamina. One intake of energy/nutrition for childbirth is Date Palm juice, a mixture of 100 grams of dates with $\pm 200 \mathrm{cc}$ of water blended using a blender. The purpose of this study was to determine the effect of dates palm juice on the duration of the first stage of labor in Sele Be Solu Hospital in Sorong City.

The research design uses Quasy Experiment (quasi-experimental) with Non-equivalent Posttest Only Control Group. Time and place of research 20 May - 15 June 2019 at Sele Be Solu Regional Hospital, Sorong City. A sample of 32 respondents using purposive sampling technique. The independent variable was giving of date palm juice and the dependent variable was the normal labor duration of the first stage of labor. Data collection used observation sheets and partographs. Statistical analysis using Independent T-Test with a significance level of 0.05 . After giving date palm juice to the intervention group p-value $=0,000 \alpha=$ 0.05 was obtained. There is an effect of Date Palm juice to facilitate normal labor duration of the first stage at Sele Be Solu Regional Hospital in Sorong City.
\end{abstract}

Keywords: Labor, First Stage, Date Palm Juice

\section{Introduction}

The labor process requires optimal energy and stamina, but there are still practices that limit food and fluid intake during labor. This is a need that must be fulfilled properly by the mother during the delivery process. Restrictions on food and beverage intake during labor can cause hypoglycemia and dehydration in labor which can affect contractions so that it can inhibit the progress of labor ${ }^{1}$.

In dates palm and every 100 grams of dates palm contain 247-93 calories, 7.0-26.1 grams of moisture, 1.7-3.9 grams of protein, 0.1-1.2 grams of fat, 72 carbohydrates , 9-77.6 grams, 2.0-8.5 grams of fiber, calcium 59-103 mg, iron 3.0-13.7 mg, potassium (potassium) $648 \mathrm{mg}$, vitamin A $15.60 \mathrm{mg}$, vitamin B1 0.03-0.09 mg, vitamin B2 0.10-0.16 mg, niacin (vitamin B or becomplex) 1.4-2.2 mg, tryptophan (oxytocin) 10$17 \mathrm{mg}$, phosphorus $72 \mathrm{mg}^{2}$
Dates contain oleic and linoleic which contribute to the provision of prostaglandins which function to strengthen and stretch the muscles of the uterus. Additionally, dates affect oxytocin receptors and make the uterine muscles respond better to oxytocin, resulting in much more effective uterine contractions ${ }^{3}$. Giving nutrition during labor must be absorbed by the body quickly and practically, one of the alternatives that can be used is to provide date palm juice. Giving date palm juice is one of the natural, non-invasive, effective, economical and safe methods for maternity mothers because date palm juice can be quickly absorbed by the body after consumption.

The labor process requires optimal energy and stamina. This is a need that must be fulfilled properly by the mother during the birth process, one of the intakes of energy and nutrition to expedite the delivery process, namely date palm juice. Date palm juice contains carbohydrates high enough to be useful for adding and storing maternal energy in labor. Dates palm affect the 
oxytocin receptors and make the uterine muscles respond better to oxytocin, resulting in much more effective uterine contractions. Therefore, the date palm is very good to be used as a date juice (Cut Mutiah Journal of the Midwifery Study Program at the Langsa Poltekes Aceh, 2017 and Ayu S. Kinanti).

Based on the background above, the authors are interested in researching" The Effect of Giving Date Palm Juice on the Duration of the First Stage of Labor in Sele Be Solu Hospital, Sorong City”.

\section{Materials and Method}

The research design used was the Quasy Experiment (quasi-experimental) with the Non-equivalent Posttest Only Control Group Design approach. This research was conducted at Sele Be Solu District Hospital in Sorong City, Sorong City.

In this study there are two variables, including date palm juice as the independent variable and the normal labor duration of the first stage which is the dependent variable.

The population in this study were first-time mothers in the Sele Be Solu District Hospital in Sorong City. The total number of respondents in the first stage of maternity in the Sele Be Solu Regional Hospital in Sorong City was obtained from the period June 1 - December 31, 2018 totaling 550 people. And the period January - February 2019 numbered 139 people with an average per month there were 70 normal maternity mothers.

The sample in this study was 32 first-stage mothers in labor who had inclusion criteria as follows: The mothers who enter the active phase of the first stage of labor and those who were willing to be respondents. Exclusion criteria included Mothers with high risk and complication labor.

After that the mothers who were in the process of the first stage were asked for approval to get some information and biodata of the mother. Before consuming palm juice, researchers first explained the
SOP of making palm juice, then each respondent was given $200 \mathrm{cc}$ of palm juice to be spent in the first stage of the process and after that the researcher observed the respondents in the first stage of the process. Labor is said to be normal if the duration of the first stage of labor for primigravida is 12-14 hours and for Multigravida 6-8 hours. Labor is said to be abnormal if the length of the first stage of labor for primigravida $>14$ hours and in Multigravida $>8$ hours.

\section{Results}

a) Frequency Distribution Based on Parity.

Table 1. Frequency Distribution Based on Maternity Parity in Sele Be Solu Regional Hospital in Sorong City.

\begin{tabular}{|l|l|l|l|}
\hline \multirow{3}{*}{ Group } & Parity & $\begin{array}{l}\text { Frequency } \\
(\boldsymbol{\Sigma})\end{array}$ & $\begin{array}{l}\text { Percentage } \\
(\mathbf{\%})\end{array}$ \\
\hline & Primi & 5 & 16 \\
\cline { 2 - 4 } & Multi & 11 & 34 \\
\hline \multirow{2}{*}{ intervention } & Primi & 2 & 6 \\
\cline { 2 - 4 } & Multi & 14 & 44 \\
\hline Amount & & 32 & 100 \\
\hline
\end{tabular}

Based on table 1 above shows that parity in the control group for primipara has the lowest frequency of 5 mothers (16\%), for multipara has the highest frequency of 11 mothers (34\%). Whereas parity in the intervention group for primipara had the lowest frequency of 2 mothers (6\%), for multiparas having the highest frequency of 14 mothers (44\%).

b) Results of Measurement of the Normal Labor Duration in the Control Group without giving date palm juice. 
Table 2. The First Stage Maternity Mother in Sele Be Solu District Hospital in Sorong City in the Control Group without giving date palm juice.

\section{TABULATION OF CONTROL GROUPS}

\begin{tabular}{|l|l|l|l|l|}
\hline Normal Labor Duration & Primi & Multi & Frequency $(\boldsymbol{\Sigma})$ & $\begin{array}{l}\text { Percentage } \\
\text { (\%) }\end{array}$ \\
\hline Normal & 3 & 6 & 9 & 56 \\
\hline Abnormal & 2 & 5 & 7 & 44 \\
\hline Amount & 5 & 11 & 16 & 100 \\
\hline
\end{tabular}

Table 2 shows the results that research respondents with primipara experienced normal labor duration by 3 respondents with a percentage (56\%) and research respondents with primipara experienced abnormal labor duration by 2 respondents with the percentage $(44 \%)$ while the research respondents with multipara experienced normal labor duration by 6 respondents with a percentage (56\%) while the research respondents with multipara experienced abnormal labor duration by 5 respondents with a percentage (44\%).

c) Results of Measurement of the Normal Labor Duration of Labor in the Intervention Group by giving Kurma Juice.

Table 3 The First Stage of labor at Sele Be Solu District Hospital in Sorong City in the Intervention Group by giving Kurma Juice.

TABULATION OF INTERVENTION GROUP

\begin{tabular}{|c|c|c|c|c|}
\hline Normal Labor Duration & Primi & Multi & Frequency $(\Sigma)$ & $\begin{array}{l}\text { Percentage } \\
\text { (\%) }\end{array}$ \\
\hline Normal & 0 & 12 & 12 & 75 \\
\hline Abnormal & 2 & 2 & 4 & 25 \\
\hline Amount & 2 & 14 & 16 & 100 \\
\hline
\end{tabular}

Table 3 shows the results that respondents with primipara experienced a smooth delivery process by 0 respondents with a percentage $(75 \%)$ and research respondents with primipara experienced by not going smoothly by 2 respondents with the percentage
$(25 \%)$ while the research respondents with multipara experienced a normal labor duration process by 12 respondents with a percentage $(75 \%)$ while the research respondents with multipara experienced abnormal labor duration process by 2 respondents with a percentage $(25 \%)$. 
d) Normality Test The Effect of Giving Date Palm Juice to facilitate normal duration of the First Stage of Labor in the Control and Intervention Groups.

Table 4 Normality Test Effect of Giving Date Palm Juice to facilitate normal duration of the First Stage of Labor in the Control and Intervention Groups.

Tests of Normality

\begin{tabular}{|c|c|c|c|c|c|c|}
\hline & \multicolumn{3}{|c|}{ Kolmogorov-Smirnova } & \multicolumn{3}{|c|}{ Shapiro-Wilk } \\
\hline & Statistic & Df & Sig. & Statistic & Df & Sig. \\
\hline Kel & .338 & 32 & .200 & .638 & 32 & .853 \\
\hline \multicolumn{4}{|c|}{ a. Lilliefors Significance Correction } & & & \\
\hline
\end{tabular}

The Kolmogorov-Smirnov test value obtained in the SPSS application, from

(a) Test the normality of data on the frequency of giving date juice to facilitate normal duration of the first stage of labor, the results of testing in the control group were found to be significant (p) $0,000>0.05$, so the data can be stated as normally distributed.

(b) Test the normality of data on the frequency of giving date juice to facilitate normal duration of the first stage of labor, the results of testing in the intervention group, the test results obtained a significant value (p) $0,000>0.05$ then the data can be declared normally distributed.

e) Test the effect of homogeneity on giving palm date juice to facilitate normal duration of the first stage of labor.

Before the hypothesis test is performed the homogeneity test is done using the Anova test. The results can be seen in table 5 .

Table 5 Test the effect of homogeneity on giving palm date juice to facilitate normal duration of the first stage of labor.

\begin{tabular}{|l|l|l|l|l|l|}
\hline \multicolumn{3}{|c|}{ ANOVA } \\
\multicolumn{2}{|c|}{ Results of Observation of the Smooth Delivery } & F & Sig. \\
\hline Between Groups & Sum of Squares & Df & Mean Square 460 & ,503 & \\
\hline Within Groups & 4,500 & 1 & 4,500 & & \\
\hline Total & 293,500 & 30 & 9,783 & & \\
\hline
\end{tabular}

The Anova Test value obtained in the SPSS application, the test results obtained a significant value (p) $0.503>$ 0.05 , the data can be said to be homogeneous. 
f) Independent T-test The effect of giving date juice to facilitate normal duration of the first stage of labor.

The results of the Independent T-test The effect of giving date juice to facilitate normal duration of the first stage of labor can be seen in the following table.

Table 6 Independent T-test The Effects of giving palm juice to facilitate normal duration of the first stage of labor.

\begin{tabular}{|l|l|l|}
\hline Variable & Mean & $\mathbf{P}=$ Value \\
\hline Control Group & 10,483 & 0.000 \\
\hline $\begin{array}{l}\text { Intervention } \\
\text { Group }\end{array}$ & 7.875 & 0.000 \\
\hline
\end{tabular}

Based on the results of the Independent T-test test explains that the effect of giving date juice to facilitate normal duration of the first stage of labor in the control group and the intervention group has the same significant value (p-value) that is $0,000<0.05$.

\section{Discussion}

The normal labor duration in mothers given Date juice is caused by it can affect the oxytocin receptors and accelerate the emergence of uterine contractions more easily to push the fetal head into the pelvic floor and shorten the duration of the latent phase of the first stage of labor ${ }^{4}$. From the research conducted there is a normal labor duration in primigravida and multigravida mothers.

Identification of the normal duration frequency of the first stage of labor from special data, it was found that the mother gave birth in the control group (who were not given date juice). For a duration scale in the first stage of labor in primipara experienced normal labor duration of 3 people (56\%), while for multipara experienced normal labor duration of 6 people (56\%). And for abnormal duration scale in the first stage of labor in primipara as many as 2 people (44\%), while for multipara experiencing abnormal duration in labor as many as 5 people (44\%).

Dates also contain hormones that help the uterus stretch for the birth of a baby. Dates affect the oxytocin receptors, stimulating the uterine muscles to respond more comfortably to oxytocin. Dates also affect the hormones progesterone and estrogen which are effective in preparing the uterus and cervical ripening ${ }^{5}$.

Parity also affects the process of accelerating labor. Mothers with primipara parity status, of course, require a longer time in the labor process, so it is necessary to provide dates juice to stimulate the acceleration of labor ${ }^{6}$. However, due to time constraints and patient availability, most of the research respondents at Sele Be Solu Hospital were in the Multipara parity with a percentage of $78 \%$. Regardless of parity status, every pregnant woman has a varying duration of labor, due to various factors, so it does not rule out the possibility of a pregnant woman with multipara parity status also requiring the provision of date palm juice to stimulate the delivery of labor and minimize risk ${ }^{7-10}$.

The control group of mothers (who were not given date juice) experienced an abnormal duration of labor due to lack of uterine rate and systole (heart contraction when blood is pumped into the arteries). Maternal women need the hormone oxytocin during labor ${ }^{11-13}$. The hormone oxytocin is a hormone that is produced in the hypothalamus and is transported through the axoplasmic flow to the posterior pituitary which, if given the right stimulation, this hormone will be released into the blood. Based on the physiological effect of accelerating labor by stimulating contraction of the uterine smooth muscle, the hormone is named Oxytocin.

This study is consistent with previous research conducted by Sabrina Dwi Prihartini ${ }^{14}$ in the Independent Practice of Midwives Mrs. Umi Salamah that there is an influence on giving of date palm juice to facilitate normal duration of of the first stage of labor. Another study conducted by Suroso Paryono in 2016 South Klaten Health Center with the title "The Effect of Consumption of Sari Palm Dates at the End of Pregnancy on the Progress of First Stage of Labor and the Number of Bleeding during Labor in Primipara in the Work Area of the South Klaten Health Center ", the result is that there is an effect on giving of date palm juice to facilitate normal duration of the first stage of labor. 


\section{Conclusions}

There is an effect on giving of date palm juice to facilitate normal duration of the first stage of labor in the Sele Be Solu District Hospital in Sorong City (P-Value $0,000<0.05$ ).

Suggestions for this research, pregnant women are advised to consider consuming palm juice for facilitating normal duration of the first stage of labor. For midwives, it is expected to provide counseling about the benefits of date palm juice on the normal duration of labor and should continue to be done following the patient's condition with a good approach before, because date palm juice does not affect the fetus or mother.

For researchers, to further deepen this study by trying to control several factors that can affect on giving of date palm juice to facilitate normal duration of labor and conduct laboratory tests so that the results obtained are more accurate, and prioritize pregnant women with primipara parity status as inclusion criteria.

Ethical Clearance : Obtained from university ethical committee

\section{Conflict of Interest : Nil}

Source of Funding : The Ministry of Health for the financial support for this research.

\section{References}

1. Cut Mutiah.. Pengaruh Pemberian Jus Kurma (Dactylifera Phoenix) Pada Ibu Bersalin Kala 1 Terhadap Durasi Persalinan. Jurnal Prodi Kebidanan Langsa Poltekes Kemenkes Aceh. 2017; $1(2): 27-32$

2. Apriyanti, dkk. Kurma dari Gurun ke Tropis. Jakarta: Trubus Swadaya 2015.

3. Ahmed, I. E. et al. 'Effects of date fruit consumption on labor and vaginal delivery in Tabuk, KSA Effects of date fruit consumption on labor and vaginal delivery in Tabuk, KSA', Journal of Taibah University Medical Sciences. Elsevier Ltd, (November). doi: 10.1016/j.jtumed.2018; 11.003.

4. Al-Kuran, O. et al. 'The effect of late pregnancy consumption of date fruit on labour and delivery', Journal of Obstetrics and Gynaecology. Taylor \& Francis, 2011; 31(1), pp. 29-31. doi: 10.3109/01443615.2010.522267.

5. Kordi, M. et al. 'The Effect of Late-Pregnancy Consumption of Date Fruit on Cervical Ripening in Nulliparous Women', Journal of Midwifery\&Reproductive Health, (Md). 2014

6. Damayanti, I. P., Maita \& Triana. Buku ajar: Asuhan kebidanan komprehensif pada ibu bersalin dan bayi baru lahir. Yogyakarta: Deepublish 2014.

7. Astwan Made. A-Z Ensiklopedia Gizi Pangan Untuk Keluarga. Jakarta: Dian Rakyat. 2009

8. Mallongi, A., Parkpian, P., Pataranawat, P., Chinwetkitvanich, S. Mercury distribution and its potential environmental and health risks in aquatic habitat at artisanal buladu gold mine in Gorontalo Province, Indonesia. Pakistan Journal of Nutrition, 2015; Volume 14, Issue 12, Pages 1010-1025

9. Ulfa $M$, et al. Effect of education media on improvement visual acetate acid inspection at Sudiang community health center. Enferm Clin. 2020. https://doi.org/10.1016/j.enfcli.2019.10.118

10. Stang, et al. Risk factor model for pulmonary tuberculosis occurrence in Makassar using spatial approach. Enferm Clin. 2020. https://doi. org/10.1016/j.enfcli.2019.10.105

11. Syam A, et al. The effect of pumpkin seed flour ( Cucurbita moschata Durch) on zinc serum levels in malnourished Wistar rats. Enferm Clin. 2020. https://doi.org/10.1016/j.enfcli.2019.10.095

12. Mallongi A, et al. Health risk analysis of phenol and arsenic exposure among kokoda communities village Sorong, West Papua. Enferm Clin. 2020. https://doi.org/10.1016/j.enfcli.2019.10.055

13. Budiani, N.N., Somoyani, N.K., Marhaeni, G.A., Erawati, L.P.S., Mallongi, A., Administration of tempehethanol extracts on prenatal until weaning inhibitory period the ovary follicles developing of little wistar rats. Indian Journal of Public Health Research and Development. 2018.

14. Sabrina Dwi Prihartini. (2014). Pengaruh Jus Kurma Terhadap Kelancaran Proses Persalinan Kala 1. Jurnal Program studi Kebidanan Fakultas Ilmu Kesehatan. 1 (2) :14. 